\title{
EL ANÁLISIS CULTURO-TRADUCTOLÓGICO EN TRADUCCIÓN. SOBRE EL MATERIAL DE CULTUREMAS EN RUDIN DE IVÁN TURGUÉNIEV Y SU TRADUCCIÓN A ESPAÑOL
}

Cultural traductological analysis in translation. On the material of culturemes in Rudin, by Iván Turguéniev and its translation into Spanich

\author{
ENRIQUE J. VERCHER GARCÍA \\ Universidad de Granada (España) \\ evercher@ugr.es
}

Resumen

En la primera parte del presente artículo se estudia la naturaleza de los denominados culturemas, entendidos como unidades semióticas cuyo referente es un elemento perteneciente a una cultura dada desconocido o sin equivalente exacto en otras culturas y que, por tanto, es percibida como una especificidad cultural. Igualmente, se analizan los criterios tanto para su clasificación tradicional por contenido referencial como su clasificación por relevancia semiótica en una traducción. En la segunda parte se aplica el método culturo-traductológico para analizar culturemas presentes en la obra de Iván Turguéniev, Rudin, y la forma de transponerlos en las diferentes versiones al español existentes por parte de distintos traductores.

Palabras clave: Traductología; culturología; culturema; método culturo-traductológico; Iván Turguéniev; Rudin; lengua rusa; lengua española.

\section{Abstract}

In the first part of this article, the nature of so-called culturemes is studied, understood as semiotic units referring to an element belonging to a given culture which is unknown or without an exact equivalent in other cultures, and which is therefore perceived as a cultural specificity. Additionally, criteria are examined for both their traditional classification by referential content, and their classification by semiotic relevance in a translation. In the second part, the culturaltraductological method is used to analyse culturemes present in Rudin, the work by Iván Turguéniev, and the way of transposing these in the different Spanish versions by different translators.

Key words: Traductology; culturology; cultureme; cultural-traductological method; Iván Turguéniev; Rudin; russian language; spanish language.

\section{INTRODUCCIÓN. DEFINICIÓN DE ESPECIFICIDAD CULTURAL Y DE CULTUREMA}

El objetivo de nuestro artículo es profundizar en las nociones de especificidades culturales y en sus unidades semióticas, los culturemas, analizar y describir profusamente numerosos ejemplos de culturemas presentes en distintas obras del escritor ruso Iván S. Turguéniev y llevar a cabo un análisis descriptivo- 
comparativo de las distintas soluciones traductológicas escogidas por diferentes traductores en sus versiones españolas de la obra analizada.

Uno de los campos más fructíferos dentro de las investigaciones traductológicas es el del análisis de la traducción de los elementos culturales. La importancia de estos elementos es tal que Vermeer llegó a proponer sustituir los términos tradicionales de lengua de partida y lengua de llegada por los de cultura de partida y cultura de llegada. Cuando un elemento cultural de una sociedad dada es desconocido o sin equivalente en otra cultura se habla de especificidad cultural.

El desarrollo del estudio de los elementos culturales o de las especificidades culturales en traducción ha ido evolucionando desde los ámbitos culturales de Nida o las palabras culturales de Newmark a los indicadores culturales de Nord o conceptos como los de realia o culturema, concepto este último en el que nos basaremos para nuestro trabajo.

El término culturema fue introducido por primera vez en 1976 por Fernando Poyatos en su obra Man beyond Words (no procede originariamente de Els Oksaar, como a veces suele pensarse, sino que esta lo tomó de Fernando Poyatos). Para Poyatos el culturema haría referencia a ciertos comportamientos culturales en ciertas situaciones recurrentes que varían según los factores culturales, verbales, no verbales y extraverbales. El término fue retomado y desarrollado por otros teóricos como Vermeer, Oksaar o Nord.

Del término culturema existen diversas definiciones que llegan a diferir sustancialmente entre sí. Nosotros nos vamos a basar en su concepción de unidad semiótica cuyo referente es un elemento (herramientas, implementos, utensilios, vestimenta, ornamentos, costumbres, instituciones, creencias, rituales, juegos, obras de arte, lenguaje, etc.) perteneciente a una cultura dada desconocido o sin equivalente exacto en otras culturas y que, por tanto, es percibida como una especificidad cultural.

El término aplicado a la Teoría de la traducción abarcaría, por tanto, todo tipo de unidades del plano de la expresión (palabras, oraciones, fragmentos, descripción de situaciones, alusiones, etc.) referidas a realidades o contextos históricos y sociales presentes en el texto original, conocidas y captadas en la lectura por el receptor del original, pero de difícil transmisión al receptor de otra cultura. Ahora bien, los culturemas pueden materializarse verbalmente en el texto de partida (así ocurriría con las realias, juegos de palabras, léxico sin equivalente o con las singularidades gramaticales directamente relacionadas con la visión del mundo de los hablantes) o pueden estar implícitos en el conocimiento que de su propia sociedad y cultura tiene el receptor nativo (gestos, costumbres, referencias culturales).

Los culturemas son un grupo abierto (a lo largo del tiempo aparecen y desaparecen culturemas en una sociedad dada), los culturemas que un hablante extranjero deba conocer para entender plenamente un texto no serán los mismos si estamos hablando del español del Siglo de Oro que del español actual. Los culturemas no existen fuera de contexto ni ajenos a una relación o transversalidad entre dos culturas (un mismo elemento puede ser un 
culturema para con dos lenguas concretas y no serlo entre otras dos lenguas con mayor afinidad cultural). Los culturemas pueden ser específicos de un país o estar compartidos por varios países; Luque Nadal (2009) pone como ejemplos de culturemas compartidos por países de tradición cristiana los de Judas (falso), Magdalena (llorar mucho), Matusalén (viejo), etc. (Luque Nadal, 2009; Molina Martínez, 2006).

Luque Nadal (2009, pp. 12-15) establece cuatro criterios para establecer qué es realmente un culturema frente a otros fenómenos que pueden tener algo de "cultural" pero no ser realmente un culturema:

1) Vitalidad, figuratividad y motivación. Los hablantes de una lengua dada deben ser conscientes del origen, motivación e implicaciones simbólicas de un elemento para ser considerado culturema. Luque Nadal pone como ejemplo la expresión "ser algo un embolao", bastante usada en la actualidad, pero de la que la mayoría de nativos desconoce su origen taurino, por lo que para el hablante medio no es algo motivado.

2) Productividad fraseológica del culturema. El culturema por definición es productivo y se caracteriza porque los fraseologismos ligados a él no presentan una forma fija, sino variaciones (dispersión fraseológica). Luque Nadal cita varios ejemplos, entre ellos el de Judas, que puede encontrarse en variaciones fraseológicas como más malo que Judas, más traidor que Judas, más falso que Judas, aparte de otras muchas y de muchas nuevas que podrían inventarse por parte de los hablantes.

3) Frecuencia de aparición en alusiones textuales, variaciones, explotaciones, chistes, etc. Es decir, que además de en fraseologismos, los culturemas pueden aparecer en chistes, publicidad, etcétera.

4) Complejidad estructural y simbólica. En palabras de Luque Nadal (2009, p. 15), "un culturema es una rutina o concatenación de causas y efectos que sirven como un programa de acción o una guía de interpretación de hechos y conductas". Frente a fraseologismos o paremias, de los culturemas se puede articular una argumentación compleja.

Nuestra concepción de culturema es más amplia que la de Luque Nadal (que estaría más cercana a la de linguoculturema), por cuanto lo entendemos como la unidad semiótica de las especificidades culturales de una cultura dada, por lo que a estos criterios añadiríamos el de la intersemiosis, entendida aquí como la característica del culturema de expresarse verbalmente o no (connotaciones, datos culturales o históricos compartidos por los hablantes de una cultura dada, gestos, costumbres...); y el de la contextualidad, es decir, que los culturemas no son entes abstractos teóricos e inamovibles, sino que se materializan en un (con) texto dado, están vivos y pueden sufrir variaciones, aparecer y desaparecer como tales culturemas (por ejemplo, el fútbol pasó de ser un culturema inglés a ser algo prácticamente universal cuando dejó de ser una especificidad cultural de aquel 
país, se extendió por otros países y pasó a ser algo conocido). Retomaremos el concepto de contextualidad del culturema más adelante.

Ya en 1945 Nida estableció cinco grupos de problemas de traducción (problemas de equivalencia) por su información cultural (Nida, 1945). Nos valdremos de dicha clasificación con algunos comentarios y pequeñas variaciones para establecer los cinco grandes grupos de culturemas por su contenido referencial, sin dejar de mencionar otras aportaciones y reformulaciones posteriores como las de Nord, Vlakhov, Florin, Newmark o L. Molina Martínez:

1) Ecología: las profundas diferencias ecológicas, climatológicas y naturales entre distintas culturas pueden provocar ciertos problemas de traducción. E. A. Nida pone como ejemplo la ausencia de cuatro estaciones diferenciadas en el Yucatán, por lo que la traducción del versículo "De la higuera aprended la parábola: Cuando ya su rama está tierna, y brotan las hojas, sabéis que el verano está cerca" (Mc 13:28) a la lengua mayayucateca puede presentar dificultades de comprensión, porque en aquella zona solo se conoce un tipo de higuera salvaje que no produce fruto, además de que pierden todas sus hojas durante la temporada cálida y le vuelven a crecer solo una vez iniciada ya la temporada de lluvias, por lo que, aun cuando se identificara la temporada de lluvias con el verano, que broten las hojas de esa planta no puede significar presagio de que el verano está cerca, sino que ya ha empezado. Conceptos como los de desierto, montaña o lago son inconcebibles para ciertas culturas y sus lenguas (Nida, 1945, pp. 196-198). En este grupo se incluirían, por tanto, culturemas referidos a cualquier elemento de la naturaleza, ya sea alguna de sus características o de sus frutos: hábitats, topónimos, animales, plantas, frutos, especificidades ecológicas, alimentos, etcétera.

2) Cultura material: con este concepto Nida se refiere a elementos como aperos de labranza conocidos o desconocidos en diferentes culturas o a tipos de asentamientos (por ejemplo, ciudades amuralladas frente a culturas en las que no existen este tipo de ciudades ni tampoco, por tanto, el concepto de "cerrar las puertas de la ciudad"). En este grupo nosotros incluiremos todos aquellos objetos que de un modo u otro han surgido de la mano del hombre y forman parte de su cultura material: ropa, utensilios, elementos urbanos, monedas, herramientas, artilugios, juguetes...

3) Cultura social: se refiere E. A. Nida a las complejidades debidas a la organización y control social. Él cita casos como la ausencia de las palabras hermano y hermana propiamente dichas en la lengua maya (sí hay palabras para indicar hermanos/as mayores o menores), la dificultad de encontrar equivalentes en ciertas lenguas para designar a la "gente común" o el problema de traducir el concepto bíblico de gentiles frente a judíos. Nosotros en este grupo incluiremos todos aquellos culturemas referidos al resultado de la organización e interacción humana, ya sean presentes (sociales) o pasadas (históricas); así por ejemplo, gestos, costumbres, relaciones de parentesco, formas de tratamiento, unidades de medida, realidades socioeconómicas 
particulares, leyes, instituciones, realidades sociopolíticas, personajes e hitos históricos, etcétera.

4) Cultura espiritual: la cultura religiosa de E. A. Nida. Este aspecto es para el autor el más "desconcertante" y cita como ejemplo la dificultad de trasladar de una cultura a otra conceptos como los de santidad, sagrado, espíritu, adivinación o títulos y nombres de divinidades. Optamos por denominar a este grupo como espiritual, ya que, además de todos los aspectos religiosos, incluiríamos también culturemas relacionados con creencias, supersticiones, fenómenos psicológicos, expresión de sentimientos y sensaciones, valores morales, prototipos y modelos que encarnen ciertos principios, etc.

5) Cultura lingüística: en este grupo se incluirían tanto las especificidades culturales surgidas a raíz de características lingüísticas (fonológicas, morfológicas, léxicas, sintácticas, supraoracionales, visiones lingüísticas del mundo) de una lengua dada (linguoculturemas), como las surgidas por el uso de la lengua como objeto de creación cultural (artística, humorística...) por parte de los nativos de esa lengua. Así, tendríamos culturemas del tipo refranes, frases hechas, juegos de palabras, particularidades lingüísticas y filológicas, nombres y apodos, etcétera.

Por el grado de importancia en la comprensión del texto podemos distinguir culturemas de relevancia semiótica alta, media o baja. El grado de relevancia semiótica no es una suerte de valor absoluto, sino que un mismo culturema puede tener mayor o menor importancia en función de la obra en que se encuentre. El culturema ya no debe entenderse, por tanto, como un concepto general teórico, sino como algo vivo, abierto y fuertemente contextualizado. Ejemplificamos la clasificación de los culturemas por su relevancia semiótica en este cuadro:

\begin{tabular}{|c|l|l|}
\hline $\begin{array}{c}\text { Tipo de culturema } \\
\text { por relevancia } \\
\text { semiótica }\end{array}$ & \multicolumn{1}{|c|}{ Descripción } & \multicolumn{1}{c|}{ Ejemplo } \\
\hline Alta & $\begin{array}{l}\text { Imprescindible para la } \\
\text { comprensión de un texto }\end{array}$ & $\begin{array}{l}\text { La palabra chamán en la obra Chamán de Siberia } \\
\text { escrita por la misma zarina Catalina II de Rusia; } \\
\text { debido a que la obra misma se titula y tiene como } \\
\text { uno de sus personajes principales a un chamán de } \\
\text { Siberia es necesario conocer en detalle qué es un } \\
\text { chamán (palabra de origen precisamente siberiano) } \\
\text { así como sus connotaciones culturales en la Rusia } \\
\text { del siglo XVIII. } \\
\text { Este ejemplo nos sirve, además, para ilustrar el } \\
\text { diferente nivel de relevancia semiótica de un mismo } \\
\text { culturema en función del contexto (obra) en que } \\
\text { aparezca; así, si bien es de relevancia alta en el caso } \\
\text { de la obra Chamán de Siberia, podría tener mucha } \\
\text { menor relevancia en otra obra en la que solo se } \\
\text { mencionara de pasada a un chamán. }\end{array}$ \\
\hline
\end{tabular}




\begin{tabular}{|c|l|l|}
\hline Media & $\begin{array}{l}\text { De relevancia elevada } \\
\text { para laplena comprensión } \\
\text { de un texto }\end{array}$ & $\begin{array}{l}\text { El carácter simbólico y polisémico que tiene el } \\
\text { apellido Raskólnikov, protagonista de Crimen y } \\
\text { castigo, para el nativo ruso, ya que procedería de la } \\
\text { alabra packon raskol con una doble acepción, } \\
\text { por un lado alude a pa3двoeнue razdvoienie } \\
\text { ("desdoblamiento"de la personalidad, por } \\
\text { ejemplo-) y por otro a pacкольничectвo } \\
\text { raskolnichestvo ("cisma", por ejemplo a los } \\
\text { denominados viejos creyentes que no aceptaron } \\
\text { las reformas de Nikon se los denomina también } \\
\text { raskólniki). }\end{array}$ \\
\hline Baja & $\begin{array}{l}\text { De relevancia menor } \\
\text { para la comprensión de } \\
\text { un texto (aunque su } \\
\text { desconocimiento puede } \\
\text { suponer la no plena } \\
\text { comprensión del texto en } \\
\text { todos sus detalles) }\end{array}$ & $\begin{array}{l}\text { Ciertas realias como por ejemplo el samovar en } \\
\text { muchas obras rusas, cuyo conocimiento no es } \\
\text { imprescindible ni de especial relevancia para } \\
\text { entender la obra. }\end{array}$ \\
\hline
\end{tabular}

Otro concepto esencial en el procedimiento de un análisis culturo-traductológico es el de equivalencia dinámica. Es decir, frente a la mera equivalencia en sus sentidos más antiguos de correspondencia linguística o de condición en una traducción para ser reconocida como válida (Vinay y Darbelnet, 1958; Nida, 1959; Catford, 1965) la equivalencia dinámica parte de la idea de la imposibilidad de la equivalencia lingüística absoluta y tiene como principio general que en el receptor nativo de otra lengua se produzca la misma reacción que en el receptor de la lengua del original. El análisis culturotraductológico de las distintas soluciones escogidas por un traductor revelarán hasta qué punto era factible y hasta qué punto se ha logrado en una traducción provocar en el receptor de la lengua (o cultura) meta la misma reacción que en el de la lengua de partida.

De este modo, traductología y exégesis cultural-literaria se acercan muy estrechamente hasta hacerse mutuamente imprescindibles. En un trabajo traductológico ya no nos vale con analizar cómo se ha vertido a la lengua (o cultura) de llegada tal o cual palabra o expresión, será necesario un análisis de la cultura y también un análisis literario del original; en nuestro caso concreto, de los culturemas analizados. Es por ello por lo que denominamos al tipo de análisis aquí estudiado análisis culturo-traductológico.

El procedimiento de análisis culturo-traductológico de culturemas deberá incluir, por tanto, estos cinco aspectos o fases:

1) Localización y confirmación de potenciales culturemas (especificidades culturales).

2) Adscripción a uno de los cinco grupos por tipo de referente indicados.

3) Análisis, descripción y búsqueda de información (histórica, social, lingüística, cultural...) del culturema.

4) Determinación de su grado de afinidad con la cultura de llegada.

168 | AlPHA № 52 (JuLIO 2021) PÁGS. 163-193. ISSN 07 16-4254 
5) Determinación de su relevancia semiótica en la traducción a otros idiomas.

6) Descripción y análisis de las soluciones traductológicas escogidas por los traductores sobre la base de la equivalencia dinámica.

Pasamos a continuación a dar algunas pinceladas acerca de algunos aspectos del pensamiento y la obra de Turguéniev que nos parecen más relevantes para el estudio culturo-traductológico que llevamos a cabo en el presente trabajo.

2. IVÁN SERGUÉYEVICH TURGUÉNIEV. ALGUNOS ASPECTOS DE SU ÉPOCA, OBRA Y PENSAMIENTO RELEVANTES PARA UN ESTUDIO CULTURO-TRADUCTOLÓGICO

Turguéniev se caracteriza por ser uno de los escritores más "occidentales" de Rusia. Sus largas temporadas en Occidente y sus deseos de introducir en su país natal gran parte de los avances y la cultura occidental le valieron las críticas de los eslavófilos, con Dostoievski a la cabeza (a lo que se sumaba una vieja disputa por una deuda económica). En ese Occidente del que hablamos España ocuparía un lugar no menor para él, aunque nunca estuvo en ella. Su amor por la cultura española daría lugar a su ensayo Hamlet y Don Quijote, obra esta última que cita literalmente en Rudin y que siempre soñó traducir al ruso sin llegar a realizarlo, a lo que podríamos añadir su amor por la cantante de origen español Paulina García.

De este modo, se suele aplicar a dos de sus personajes más famosos, Bazárov y Pável Petróvich (Padres e hijos), las dos categorías esenciales de persona que distinguía Turguéniev: los hamlets y los quijotes. Pero ya sabemos que no existe un solo Quijote universal, sino que ha sido interpretado de diferentes maneras a lo largo de los siglos por diferentes personas (con casos curiosos como el de Kamiński, quien incluye en su traducción y adaptación juvenil al polaco una interpretación didáctica y moralizadora, criticando la postura de don Quijote fuera de la realidad, frente a la laboriosidad y capacidad previsora de Robinson Crusoe). Así pues, estaríamos ante la interpretación y adaptación de un personaje elevado a culturema español por parte de un autor ruso; con lo que irónicamente nuestro trabajo es la interpretación de un español de la interpretación que hace un ruso de un culturema español.

Para los occidentalistas el aspecto político es esencial. Sus principales ideas eran el apoyo al pensamiento ilustrado occidental, la crítica a la autocracia rusa, los derechos del individuo, como la libertad y la dignidad, y la relativización de la importancia de las raíces históricas y nacionales rusas. Uno de los mayores ataques que recibían por parte de los eslavófilos era el de sentirse en cierto modo avergonzados de esas raíces culturales rusas. Ciertamente el positivismo, el materialismo y el socialismo occidentales decimonónicos estarán muy presentes en el esquema de pensamiento de los occidentalistas; del mismo modo, los occidentalistas relativizarán la importancia del cristianismo ortodoxo. 
Sin embargo, tanto unos como otros tienen en común considerar que existe mucha pobreza en Rusia, que debe haber cambios a mejor. Por tanto, esa visión generalizada negativa, al menos en esos aspectos, se eleva a condición de culturema y debe ser tenido en cuenta por el traductor y el lector occidental. Es por ello que resulta especialmente interesante el análisis de las traducciones de culturemas rusos a español de un autor que siendo tan ruso se caracteriza por su occidentalismo.

Una de las facetas culturales específicas de Rusia más importantes de la época que le tocó vivir a Turguéniev es la de la existencia todavía de la servidumbre, es decir, de siervos de la gleba (frecuentemente ser referían a ellos en ruso como almas) sujetos a una tierra y que podían ser comprados y vendidos por su señor, recibir castigos físicos, etc. La acción, como decíamos, tiene lugar poco antes de su abolición, y ya muchos terratenientes habían pasado del antiguo sistema de servidumbre a ceder tierras a los campesinos en aparcería bajo pago de unos correspondientes tributos. Esto se veía ya como algo de justicia incluso por personas no especialmente progresistas. Vasili Ivánich, padre de Bazárov, afirma lo siguiente:

-No diré que yo, por ejemplo, no haya hecho notables sacrificios para pasar los campesinos al sistema de tributo y entregarles mis tierras en arriendo. Consideraba esto como mi deber, lo más sensato en este caso, aunque a otros terratenientes ni siquiera se les haya ocurrido: me refiero a las ciencias, a la inistrucción (trad. de Zúñiga, p. 173).

Las especificidades culturales se muestran en la figura misma del pequeño terrateniente ruso de mediados del siglo XIX. En Turguéniev y sus lectores hay toda una serie de connotaciones en torno a esta figura social, se trata de hombres que no sabían administrar sus propiedades, faltos de higiene y no rara vez alcohólicos, con frecuencia sumidos en la desidia y el aburrimiento, que solo aspiraban a codearse con la alta nobleza peterburguesa y que, en definitiva, veían cómo su mundo se derrumbaba.

Teniendo en cuenta la falta de libertad y la férrea censura de la época zarista, acaso algo aliviada con la llegada de Alejandro II (1855-1881), la crítica de Turguéniev a ese mundo de servidumbre necesariamente debía ser muy sutil. Esta sutileza, estas connotaciones apenas perfiladas, este leer entre líneas forma parte de la especificidad cultural del mundo descrito y es lo que resumidamente nos proponemos desentrañar.

Es importante mencionar aquí por su relevancia lingüística y cultural, la importancia de la lengua francesa y su extendido uso, especialmente entre las clases altas, de la Rusia de los siglos XVIII y XIX. En Rudin llegamos a leer: "Daria Micaelovna se expresaba en ruso, y parecía orgullosa de su perfecto conocimiento de la lengua materna; sin embargo, dejaba escapar a menudo galicismos y palabras francesas. Quería hacer uso de palabras sencillas y expresiones populares, lo que no siempre conseguía. A Rudín no le molestaba aquella mezcolanza de lenguaje que fluía de los labios de Daria Micaelovna”. 
Conviven, por tanto, el estilo de vida (y esto incluye costumbres, bienes materiales, forma de hablar, referencias culturales, etc.) más tradicional ruso, presente sobre todo en los campesinos y clases populares, por un lado, y el estilo de vida occidentalizante, sobre todo afrancesado, más propio de la nobleza (también la pequeña nobleza, no solo la alta aristocracia). Esto está presente a lo largo de todo Rudin.

Aplicamos a continuación el procedimiento de análisis culturo-traductológico que hemos descrito anteriormente a culturemas presentes en la obra Rudin de Iván Turguéniev y las distintas soluciones elegidas por sus traductores. Analizamos las siguientes traducciones a español: 1. La traducción anónima aparecida en 1893 en el número LVII de la revista La España Moderna (también publicada por la misma $L a$ España Moderna en forma de libro); 2. la de María Rosa Turuguet publicada en 1942 por la editorial Nausica; 3. la realizada por Rafael Cansinos Assens y publicada en 1951 por la editorial Aguilar; 4. la traducción aparecida en 1954 en el número 1.189 de Revista literaria. Novelas y cuentos $^{1}$; 5 . la traducción de Aníbal Leal publicada en Argentina en 1981 por Javier Vergara Editor; 6. la llevada a cabo por Jesús García Gabaldón y publicada en 1997 por Alba Editorial.

\section{ANÁLISIS DESCRIPTIVO Y COMPARACIÓN DE CULTUREMAS RUSOS PRESENTES EN RUDIN DE TURGUÉNIEV EN LAS TRADUCCIONES A LA LENGUA ESPAÑOLA}

\subsection{ECOLOGÍA}

Las particularidades de la naturaleza, la flora y la fauna de cada cultura pueden crear culturemas conocidos para los miembros de dicha cultura que hagan referencias a asociaciones de ideas o connotaciones desconocidas para individuos de otra cultura ajena.

Analizamos un primer caso presente en la novela de Rudin que nos ha parecido curioso. Veamos en primer lugar el pasaje:

$-[\ldots]$ Отчего ты не мог ужиться в гимназии, отчего ты -странный человек!

- с какими бы помыслами ни начинал дело, всякий раз непременно кончал его тем, что жертвовал своими личными выгодами, не пускал корней в недобрую почву, как она жирна ни была?

- Я родился перекати-полем, -продолжал Рудин с унылой усмешкой. -Я не могу остановиться (Эпилог).

\footnotetext{
${ }^{1}$ Aunque se trata de una traducción anónima de la que no se indica el traductor, se advierte que se basa claramente en la de María Rosa Turuguet con muy ligeras variaciones y con las mismas soluciones traductológicas en la mayoría de los casos (traducir izba como cabaña, lezhanka como estufa, etc.), así como la misma organización en XIII capítulos + epílogo, en vez de XII capítulos + epílogo como el original; de hecho, podría ser una versión de la misma traductora ligeramente corregida.
} 
En este diálogo, cuando Lezhnev le pregunta sorprendido a Rudin por qué nunca echó raíces en ningún sitio, este le responde usando una planta como símil de persona que siempre necesita ir desplazándose de un lado para otro. Se trata de lo que en ruso se denomina перекати-поле (perekati-pole), de perekatit' 'rodar' у pole 'campo', y en español estepicursor, término que hace referencia a varias especies de plantas que se desplazan rodando (formando a veces grandes esferas). Su grado de relevancia semiótica según el cuadro que hemos introducido sería baja, pues realmente no es un elemento esencial para entender la novela, pero sí que nos parece un delicioso ejemplo de culturema de este primer grupo estudiado. Aunque el grado de afinidad con la cultura de llegada es bastante elevado, pues ese tipo de plantas también se conocen en el mundo hispánico, nos ha parecido interesante como culturema, pues se aprecia una diferencia en las alusiones y connotaciones que tiene para la cultura española y rusa. Mientras que para el lector español suele ser símbolo de lugar desierto y desangelado (piénsese en las películas del Oeste, por ejemplo), en Rusia (aun cuando hoy también se asocia como algo característico de las películas del Oeste) siempre se ha usado como símbolo de persona que vaga de un lugar a otro sin echar raíces en ningún sitio. Es decir, se trata de un culturema fácilmente reconocible por un lector español (por el contexto inmediatamente entenderá que hace una comparación entre su modo de vivir errante y este tipo de plantas que van rodando de un sitio a otro), pero no fijado como tal en la cultura española, como sí lo está en la rusa.

A pesar de que en la lengua española existen muchas palabras para referirse a este tipo de plantas, tanto la genérica de estepicursor como otras más dialectales del tipo rodamundos, sorrasca, churumico, calamino, boja, salicón, salicor, salicornio, alicornio o incluso cardo ruso, entre otras muchas, el traductor de La España Moderna optó por transliterar dejando el pasaje en español del siguiente modo:

$-[\ldots]$ ¿Por qué no has podido vivir en el Instituto? ¿Por qué, hombre extraño, cuando emprendías un negocio lo abandonabas, sacrificando tus propios intereses y sin echar raíces en ninguna tierra, por fértil que fuera?

-Yo soy perecatipol de nacimiento -dijo Rudín ${ }^{2}$, con humilde sonrisa-. No puedo detenerme.

Y añade una nota a pie de página con la siguiente aclaración: "Planta que crece en las estepas y que echa raíces allí donde la va llevando el viento".

María Rosa Turuguet (y la traducción de Revista literaria de 1954) también optó por transliterar y vemos que su traducción debió de beber bastante de la de 1893:

\footnotetext{
${ }^{2}$ El traductor de La España Moderna, María Rosa Turuguet y el traductor de Revista literaria acentúan Rudín (con acento en la $i$ ). Fenómeno curiosamente frecuente entre los hispanohablantes, que a menudo cambian de lugar el acento de muchas palabras rusas.

172 | AlPHA № 52 (JuLIO 2021) PÁGS. 163-193. ISSN 07 16-4254
} 
-[...] ¿Por qué no has podido vivir en el instituto? ¿Por qué, hombre raro, cuando emprendías un negocio lo abandonabas, sacrificando tus propios intereses y sin echar raíces en ninguna tierra, por fértil que fuera?

-Yo soy perecati-pole de nacimiento -respondió Rudín, con humilde sonrisa-. No puedo detenerme en parte alguna.

Y añade la siguiente nota a pie de página: "Planta que nace en las estepas y cuya naturaleza es echar raíces allí donde la lleva el viento", quizá no del todo acertada como explicación del culturema, pues resalta el hecho de cómo echa raíces, cuando en el texto se usa precisamente para enfatizar el hecho de errar de un lado para otro sin asentarse en ninguno. Rafael Cansinos Assens, por su parte, traduce el pasaje en su versión del siguiente modo:

-[...] ¿Por qué no pudiste acomodarte al gimnasio, por qué..., hombre extraño?... Siempre que empezaste una cosa con buena intención, terminaste sacrificando tus intereses personales y sin echar raíces en una tierra mala, por crasa que fuere.

-Yo he nacido para volar-dijo Rudin con triste sonrisa-. Y no puedo detenerme.

Como podemos apreciar, ha realizado una adaptación del culturema valiéndose de una traducción más libre, pero conservando la idea que pretendía transmitir el original. En la versión de Aníbal Leal leemos:

-[...] Y por qué no pudiste continuar trabajando en tu liceo... ¡qué hombre extraño! ¿Por qué sacrificaste siempre tu provecho personal, cualesquiera fuesen tus proyectos? En definitiva, ¿por qué jamás arraigaste aunque fuese en una tierra refractaria, si tú sabías que podía llegar a ser fecunda?

-Nací para rodar de un lugar a otro -respondió Rudin con una sonrisa fatigada-. No puedo detenerme.

También este traductor sacrifica la imagen del culturema y la fuerza literaria del mismo en pos de trasladar más claramente al lector el sentido. Jesús García Gabaldón, finalmente, opta por una traducción mucho más libre y que se aleja del culturema empleado por el original. Su versión del pasaje suena así:

-[...] ¿Por qué no pudiste acostumbrarte a la vida del Instituto? ¿Por qué tú, hombre extraño, cualesquiera que fueran tus propósitos al empezar una empresa, la acababas infaliblemente sacrificando tus intereses personales, y no echabas raíces en una tierra mala, por muy fértil que fuera?

-Nací siendo un villano -replicó Rudin con triste sonrisa-. No puedo pararme.

Como podemos observar, en esta última traducción además de no reflejarse el culturema tal y como aparece en el original, no queda clara la conexión entre ser un "villano" y no poder detenerse. 
Dentro de este grupo, según hemos indicado, incluimos alimentos, comidas y bebidas. Un ejemplo de culturema ruso empleado por Turguéniev es cuando el personaje de Pigasov afirma:

ДажеПигасов молчал и, когда Дарья Михайловна заметила ему, что он очень нелюбезен сегодня, угрюмо ответил: “Когда же я бываю любезным? Это не мое дело...” и, усмехнувшись горько, прибавил: “Потерпите маленько. Ведь я квас, du prostoї русский квас; а вот ваш камер-юнкер...” (гл. II).

Kvas es una bebida fermentada a base de centeno muy popular en Rusia y otros países del este de Europa. Aquí el personaje lo emplea como alusión a que es un hombre sencillo, del pueblo, un ruso auténtico, castizo. Posee como culturema una relevancia semiótica baja, pues no afecta a la comprensión esencial de la novela. Tiene, por otro lado, un grado de afinidad baja con la cultura de llegada (en este caso la española), pues es una bebida desconocida para la mayor parte de los lectores españoles. La traducción de 1893 de La España Moderna presenta el pasaje del siguiente modo:

El mismo Pigassof se callaba, y cuando Daria Micaelovna le hizo observar que no estaba amable este día, respondió con tono melancólico:

- ¿Y cuándo soy amable? Eso no va conmigo. $-\mathrm{Y}$ añadió con amarga sonrisa-: Tenga V. paciencia; mire V., yo soy kvass, simple kvass ruso, mientras que su gentilhombre de cámara...

El culturema no se intenta transmitir de ningún modo ni se explica en forma de nota, por lo que el lector español, aun cuando busque información acerca de lo que es el kvas (con una $s$, y no con dos como, incomprensiblemente, escribe el traductor), no percibirá las connotaciones del original.

María Rosa Turuguet y el traductor de la versión de Revista literaria traducen el fragmento del siguiente modo:

Pigassoff se callaba y, cuando Daria Micaelovna le hizo observar que aquel día no se mostraba demasiado amable, le respondió con aire melancólico: "¿Cuándo me muestro amable, yo? No es mi especialidad...”. Y añadió con amarga sonrisa: "Tenga paciencia; yo soy kvass, simple kvass ruso, mientras que su gentilhombre..."

Pero ella al menos añade una nota a pie de página: "Bebida fermentada de la que se hace gran consumo en Rusia". Nota similar añade el traductor de Revista literaria. En la versión de Rafael Cansinos Assens leemos este pasaje como sigue:

Incluso Pigasov callaba, y como Darya Mijailovna le hiciera observar lo poco simpático que resultaba aquel día, contestóle malhumorado:

- ¿Es que alguna vez fui simpático? Ese no es mi fuerte...-Y con amarga sonrisilla, añadió-: Tenga un poco de paciencia. Porque yo soy kvas, kvas, ruso auténtico..., pero su kamer-junker... 
El traductor no intenta transmitir el culturema ni añade ninguna nota o aclaración, con lo que las connotaciones del original comprensibles para un lector ruso pueden perderse ante el lector español.

Aníbal Leal traduce como "yo no soy más que un pequeño kwass, un sencillo kwass", por lo que dado el uso del adjetivo "pequeño" para referirse al kwass y dado el uso del artículo indeterminado, no está claro que el traductor sepa que kvas se refiere a una bebida y no a ningún objeto. Además, sorprende la forma de la transliteración (kwass), que parece haber sido tomada del inglés o el alemán.

J. García Gabaldón, por su parte, opta también por transliterar kvas ("yo soy kvas, auténtico kvas ruso..."), y añade una nota a pie de página: "bebida fermentada rusa".

\subsection{Cultura material}

Según explicábamos anteriormente, este grupo englobaría todos aquellos utensilios, elementos urbanos, monedas, herramientas, artilugios, juguetes, herramientas, aperos y otros objetos materiales característicos de la cultura de partida. Las obras de Turguéniev están repletas de culturemas de este tipo, característicos de la Rusia del siglo XIX.

Nos vamos a valer del siguiente fragmento de Rudin, donde aparecen varios culturemas materiales, para comentarlos desde el punto de vista traductológico:

Александра Павловна вошла в избу. В ней было и тесно, и душно, и дымно... Кто-то закопошился и застонал на лежанке. Александра Павловна оглянулась и увидела в полумраке желтую и сморщенную голову старушки, повязанной клетчатым платком. Покрытая по самую грудь тяжелым армяком, она дышала с трудом, слабо разводя худыми руками. (гл. I).

Lezhanka (лежсанка) es un vocablo ruso que hace referencia al poyo, normalmente de piedra o ladrillo, bajo el que se ubicaba una estufa para dar calor. Era un lugar donde se pasaba bastante tiempo realizando labores caseras (como bordar) mientras se "pelaba la pava". P. V. Annenkov escribe en una carta de 1875 dirigida precisamente a I. S. Turguéniev, hablando del cuadro La aldea de Malinovka de Jean-Louis-Ernest Meissonier: "От нее веет чистой, целомудренной девической спаленкой и рабочей комнаткой, с анализом, который в них помещается обыкновенно, как кот на лежанке" ('Se respira en él el ambiente del dormitorio y del cuarto de trabajo de una muchacha limpia y casta, con un tratamiento de lo que suele haber en ellos, como un gato sobre una lezhanka'). Suele transmitir connotación de calor, comodidad, lugar acogedor. La imagen de la carta es la de un gato sentado placenteramente en la lezhanka.

Se trata de un culturema sin un equivalente directo en la cultura española, al menos de manera generalizada. Su relevancia semiótica en la traducción es baja, pues no es un 
elemento esencial para entender el desarrollo de la novela. El conjunto de culturemas de este tipo, no obstante, ayudan a describir y transmitir cómo era la vida en la Rusia de aquella época y de ese ambiente rural.



Imagen de lezhanka de construcción moderna.

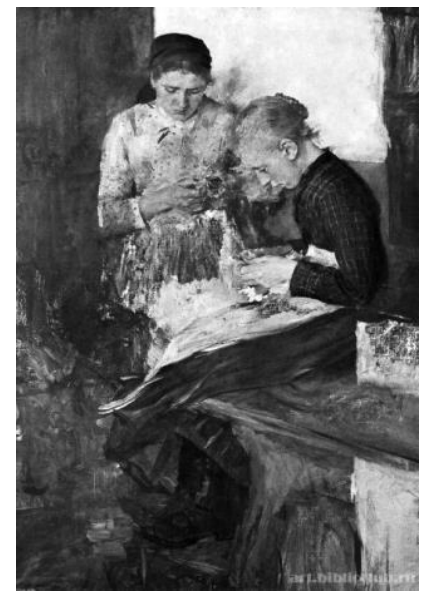

Muchachas bordando sentadas en una lezhanka (W. M. H. Leibl).

La traducción anónima de 1893 traslada a español el pasaje del siguiente modo:

Alexandra Pavlovna entró en la choza, estrecha, llena de humo, con un calor sofocante... Alguien se agitaba y gemía encima del fogón. Alexandra Pavlovna echó una mirada en torno suyo, y distinguió entre la semioscuridad la cara amarilla y arrugada de una vieja, con la cabeza envuelta en un pañuelo a cuadros. Cubríala hasta el pecho un pesado caftán. Respiraba con esfuerzo y removía débilmente las enflaquecidas manos.

La palabra fogón en español se refiere al lugar para cocinar, pero en el imaginario español no se encuentra la posibilidad de tumbarse sobre él, por lo que este culturema material suena extraño en la traducción. El cuadro descrito aparece en la traducción de Rosa María Turuguet del siguiente modo:

Alejandra Paulovna entró en la cabaña. En su interior apenas uno podía moverse; las paredes estaban ennegrecidas por el humo, el calor era sofocante. Alguien se movía y gemía encima de la estufa. Alejandra Paulovna echó una mirada a su alrededor y distinguió en la penumbra el rostro amarillo y arrugado de una vieja, cuya cabeza estaba envuelta con un pañuelo a cuadros. Un pesado caftán la cubría hasta el pecho; respiraba con dificultad y no cesaba de mover débilmente sus enflaquecidas manos.

La traductora opta por añadir una nota a pie de página: "Los campesinos pobres duermen habitualmente sobre sus estufas". Como hemos mencionado anteriormente en 176 | AlPHA № 52 (JuLIO 2021) PÁGS. 163-193. ISSN 07 16-4254 
una nota, también el traductor anónimo de Revista literaria traduce lezhanka como estufa. Rafael Cansinos Assens traduce el fragmento del siguiente modo:

Alexandra Pavlovna entró en la isba. Reinaban en ella oscuridad, ahogo y bruma... Alguien se revolvía y quejaba en un camastro. Miró Alexandra Pavlovna y vislumbró en aquella penumbra la amarillenta y arrugada faz de una anciana, con la cabeza envuelta en un pañuelo a cuadros. Cubierta hasta el pecho por pesado corpiño, alentaba con dificultad, moviendo débilmente las manos.

El traductor realiza una traducción de la palabra que no transmite del todo el objeto real. Tampoco añade ninguna nota ni aclaración, por lo que el culturema como tal se pierde. Aníbal Leal en su versión opta por transliterar ("alguien se movió y gimió sobre la liejaneka") y añadir la siguiente nota a pie de página: "chimenea baja usada como cama".

Finalmente, la versión de Jesús García Gabaldón usa también como traducción camastro y se presenta así:

Alexandra Pávlovna entró en la isba. Dentro se estaba muy estrecho, en un ambiente sofocante y ahumado. Alguien se revolvía y gemía en un camastro. Alexandra Pávlovna echó un vistazo y en la penumbra vislumbró la cabeza amarillenta y arrugada de la anciana, envuelta en un pañuelo a cuadros. Cubierta hasta el pecho por un tabardo, respiraba con dificultad separando débilmente sus manos enjutas.

De este fragmento podemos comentar también el culturema material armiak (армяк), palabra de origen túrcico que se define como "ropa de abrigo masculina campesina, hecha de tela gruesa en forma de bata o caftán recto con capucha larga" y que los diccionarios traducen como "tabardo". En el fragmento vemos que es una anciana quien lo lleva puesto. Turuguet opta por traducirlo mediante una palabra que transmite aproximadamente la imagen del original pero que es comprensible para el lector español medio (caftán), mientras que Cansinos Assens opta por traducirlo como corpiño, lo que no es exacto y puede dar una idea equivocada. J. García Gabaldón se vale del citado vocablo tabardo.

Podríamos añadir finalmente el caso de izba (избa), casa hecha de troncos de madera característica de la Rusia rural. Es un vocablo quizá más conocido para el lector español, traducido, no obstante, por la versión de 1893 como choza y como cabaña por Turuguet, mientras que Cansinos Assens, Aníbal Leal y García Gabaldón optan por transliterar (isba), nuevamente sin añadir ninguna aclaración.

\subsection{CULTURA SOCIAL}

Las relaciones sociales en Rusia en tiempos de Turguéniev eran complejas, y aunque dominadas por el régimen de servidumbre, del que ya hemos hablado anteriormente, han 
ido evolucionándose y viéndose influenciadas por Occidente, con lo que podemos encontrar toda una serie de figuras (y sus distintas maneras de denominarlas en ruso).

Encontramos, así, la figura de la компаньонка (kompanionka), la dama de compañía (procede etimológicamente del francés compagnon "compañero" y supone el equivalente de la figura francesa de la dame de compagnie), una innovación (su referencia más antigua en el Corpus Nacional de la Lengua Rusa es de 1834, en la obra de N. A. Polevoy Emma, y usándola ya Turguéniev apenas en la década siguiente) occidentalizante con respecto a la tradicional служсанка (sluzhanka) "criada" rusa. Algunas familias trataban de resaltar su carácter más "progresista" usando figuras como estas y ataviándolas claramente como tales. Es lo que vemos en el siguiente pasaje de Padres a hijos:

У дверей, над криво прибитою визитною карточкой, виднелась ручка колокольчика, и в передней встретила пришедших какая-то не то служанка, не то компаньонка в чепце - явные признаки прогрессивных стремлений хозяйки.

La idea que transmite el pasaje se mantiene en todos los traductores, pero es interesante especificar la variante que usa cada uno: señorita de compañía (Revista Internacional, J. E. Zúñiga y R. Cañete Fuillerat), doncella (R. Cansinos Assens) y dama de compañía (B. Martinova), siendo seguramente esta última la más acertada.

Otra figura característica de la época sería el del guvernër (гувернёр), si era hombre, guvernantka (гувернантка) en el caso de una mujer, del francés gouverneur y gouvernante, el institutor o institutriz, normalmente de cierta edad, que se encargaba de la educación de los hijos dentro del hogar. Esta figura apareció en Rusia en tiempos del zar Pedro I (aunque la primera cita del ruscorpora es de 1789), caracterizado por sus políticas modernizadoras y occidentalizantes. El grado de afinidad con la cultura española es bastante elevado, porque también en España existía esta figura, aunque las connotaciones podían ser un poco diferentes. La encontramos en este pasaje de Rudin:

$\mathrm{C}$ другой m-lle Boncourt - гувернантка, старая и сухая дева лет шестидесяти, с накладкой черных волос под разноцветным чепцом и хлопчатой бумагой в ушах (гл. II).

En esta obra la relevancia semiótica de la institutriz es de grado medio, se trata de un personaje que aparece varias veces y que sirve para describir la situación social de la familia. No obstante, no juega ningún papel relevante como tal institutriz ni sus acciones como institutriz condicionan ningún acontecimiento. Encontramos este culturema erróneamente traducido en la versión de María Rosa Turuguet, quien lo traduce como dama de compañía, y en la versión de 1954, donde se traduce como dama de compañía. La traducción Turuguet del pasaje citado sería la siguiente: 
Al otro lado había la señorita Boncourt, la señorita de compañía, una solterona seca de carnes que aparentaba unos sesenta años; llevaba un rodete de cabello negro bajo una cofia de cintas abigarradas, y algodón en rama en los oídos.

R. Cansinos Assens, en cambio, acierta con su traducción:

Y del otro, mademoiselle Boncourt, la institutriz, una solterona vieja y seca, de unos sesenta años, con el pelo negro postizo bajo una cofia de colorines y un algodoncito en los oídos.

Aníbal Leal se vale en su traducción de un calco (gobernanta) sin que el sentido de esa palabra sea exactamente el equivalente al de guvernantka en ruso:

[...] y la señorita Boncourt, la gobernanta. Esta, una anciana enjuta, de unos sesenta años, tenía puesto un gorro de colores abigarrados sobre un falso tupé de cabellos negros, y tenía algodón en las orejas.

Y también J. García Gabaldón traduce como institutriz:

[...] y del otro, mademoiselle Boncourt, la institutriz, una vieja y seca solterona de unos sesenta años, con el pelo negro postizo bajo una colorida cofia y con unos algodoncitos en los oídos.

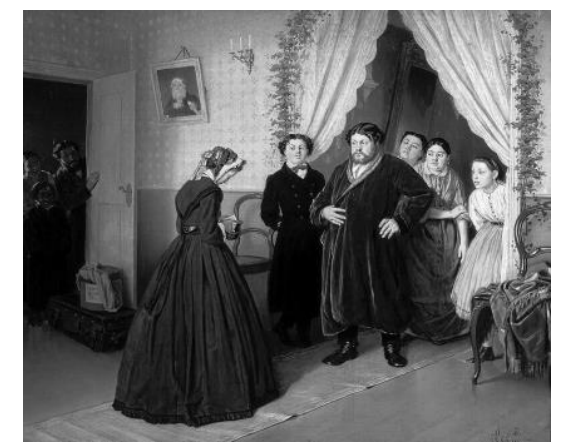

La llegada de la institutriz a casa de un mercader (V. Perov).

\subsection{Cultura eSPIRITUAL}

Dentro de este grupo podríamos incluir numerosos culturemas con mayor o menor afinidad a la cultura española. En el primer caso tendríamos, por ejemplo, alusiones a prototipos literarios o históricos que encarnan ciertos principios o actitudes vitales (así, en Rudin se habla de ser una Mecenas, un Tartufo, de ser los últimos mohicanos, etc.). Entre los de menor afinidad con la cultura española podríamos citar numerosas supersticiones existentes en la cultura rusa pero desconocidas en la española.

Traemos a colación en este apartado un fragmento de Rudin en el que el personaje de Lezhnev, para insinuar que la deshonestidad y cinismo de Rudin, se vale ingeniosamente de una alusión a unos versos de Griboyédov. El pasaje en el original reza así: 
- Вас оскорбляет его превосходство - вот что! - заговорила с жаром Александра Павловна, - вот что вы ему простить не можете. А я уверена, что, кроме ума, у него и сердце должно быть отличное. Вы взгляните на его глаза, когда он...

- “О честности высокой говорит...” - подхватил Лежнев.

- Вы меня рассердите, и я заплачу. Я от души сожалею, что не поехала к Дарье Михайловне и осталась с вами. Вы этого не стоите. Полноте дразнить меня, - прибавила она жалобным голосом. - Вы лучше расскажите мне об его молодости (гл. V).

"О честности высокой говорит..." es una cita del personaje de Repetilov de $E l$ mal de la razón de Griboyédov (1795-1829). Se usa como comentario irónico para referirse a una persona deshonesta o con unos principios morales cínicos. El grado de afinidad a la lengua de llegada es bajo por cuanto el lector español no suele conocer esta alusión, aun cuando por el contexto del pasaje pueda entenderlo. La relevancia semiótica es media, pues aun no siendo esencial para la comprensión de la historia, sí que ayuda a comprender la opinión de Lezhnev respecto de Rudin, el protagonista. En la versión de 1893 de La España Moderna leemos el pasaje en español del siguiente modo:

-La superioridad de Rudín le ofende a V., y por eso no le quiere -dijo Alexandra Pavlovna con fuego-. Eso es lo que no puede V. perdonarle. Y estoy segura de que la amplitud de su talento no obsta para la bondad de su corazón. Mire V. sus ojos, cuando...

-Cuando del perfecto honor, entusiasmado, nos habla... -interrumpió Lejnieff, citando un verso de Griboiedoff.

-Me enfadará V y me echaré a llorar. Siento con toda mi alma no haber ido a casa de Daría Micaelovna, en lugar de estar aquí con V. Así, pues, deje V. de contrariarme - continuó, con voz quejumbrona-. Mejor sería que me contase V. alguna cosa de su juventud.

Y añade una nota a pie de página con el siguiente texto:

Cuando del perfecto honor

Entusiasmado nos habla,

Inyéctasele de sangre

Toda la piel de la cara,

Y los ojos le relumbran,

Y vierte un raudal de lágrimas;

Y nosotros sollozamos...

Estos versos de Groboiedoff [sic] aluden a un hipócrita redomado.

María Rosa Turuguet, basándose en la versión de 1893 y usando sus referencias, traduce el pasaje del siguiente modo: 
-La superioridad de Rudín le molesta, por eso no le quiere -dijo Alejandra Paulovna, excitada-; esto es lo que usted no le perdona. Y estoy persuadida de que su inteligencia corre parejas con la bondad de su corazón. Solo hay que verle los ojos cuando...

-Cuando habla del perfecto honor... -interrumpió Lejnieff, citando unos versos de Griboiedoff.

-Me enfadaré y romperé a llorar. Siento profundamente no haber ido a casa de Daria Micaelovna, en vez de haberme quedado aquí. Usted no se lo merece. No me contraríe -prosiguió con voz quejumbrosa-. Mejor sería que me contase algo de su juventud.

La traductora, como vemos, soluciona el problema traductológico añadiendo en su traducción la aclaración “citando unos versos de Griboiedoff” y una nota a pie de página:

Cuando habla del perfecto honor,

su rostro se congestiona,

sus ojos centellean,

llora, y nosotros...

nosotros sollozamos.

(Estos versos aluden a un hipócrita).

El pasaje, como viene siendo habitual, es prácticamente idéntico en la versión de Revista literaria de 1954. R. Cansinos Assens vierte al español el pasaje del siguiente modo:

-A usted le duele su valer, eso es todo -observó con vehemencia Aleksandra Pavlovna-. Por eso no lo perdona. Pero yo estoy convencida de que además de talento debe de tener también un gran corazón. ¿Le miró usted a los ojos cuando...? - ¿De la alta honradez habla...? -dijo con énfasis Lechniov.

-Usted me disgusta y va a hacerme llorar. Lamento en el alma no haber ido a casa de Darya Mijailovna y haberme quedado con usted. No se lo merece. Deje usted de irritarme -añadió con voz lastimera-. Mejor será que me cuente algo de su juventud.

Como podemos observar, el traductor no ha intentado trasladar el culturema mediante ninguna técnica ni ha incluido una nota o aclaración, con lo que el culturema en su versión español se pierde. Lo mismo ocurre con la traducción de Aníbal Leal, quien traduce la réplica de Lezhnev como "... habla de la más excelsa probidad” sin dar mayor explicación de la referencia cultural de esa frase.

Otro culturema dentro de este grupo sería el de Pechorín, personaje literario y protagonista de Un héroe de nuestro tiempo de Lérmontov que encarna el prototipo de hombre taimado que es amado por mujeres aun no mereciéndolo. Lérmontov y especialmente su citada novela fueron objeto de numerosos imitadores. Lo encontramos en el siguiente pasaje de Rudin: 
- Из-за границы, - продолжал он, - Рудин писал к своей матери чрезвычайно редко и посетил ее всего один раз, дней на десять... Старушка и скончалась без него, на чужих руках, но до самой смерти не спускала глаз с его портрета. Я к ней езжал, когда проживал в Т...ве. Добрая была женщина и прегостеприимная, вишневым вареньем, бывало, всё меня потчевала. Она любила своего Митю без памяти. Господа печоринской школы скажут вам, что мы всегда любим тех, которые сами мало способны любить; а мне так кажется, что все матери любят своих детей, особенно отсутствующих (гл. V).

Es decir, Lezhnev lo usa como modo de ejemplificar el amor que la madre de Rudin sentía por su hijo a pesar de no merecerlo este. De relevancia semiótica baja para la comprensión general de la novela, se trata de un culturema sin equivalente exacto, pero de fácil comprensión por el contexto. El traductor anónimo de La España Moderna tradujo el fragmento del siguiente modo:

-Una vez que hubo partido - prosiguió- Rudín escribía muy de tarde en tarde a su madre. No fue a verla sino una vez, y eso para dos días nada más. La pobre mujer murió rodeada de extraños, lejos de él, pero sin perder de vista su retrato hasta el último trance. Era una mujer excelente, muy hospitalaria. Iba yo a verla, cuando estaba ella en $\mathrm{T}^{* * *}$, y nunca dejó de obsequiarme con dulce de cerezas. Amaba a su hijo con locura. Los señores de la escuela de Petchorín os dirán que siempre somos propensos a amar a los que están menos dispuestos a la ternura; pero a mí me parece que todas las madres aman a sus hijos, sobre todo a los que están ausentes.

Y añade la siguiente nota a pie de página: "Protagonista de una novela de Lermontoff". María Rosa Turuguet tradujo el pasaje en su versión del siguiente modo:

-Una vez separado de su madre -prosiguió- le escribía muy de tarde en tarde. Solo fue a verla una vez, y únicamente por dos días. La pobre mujer murió rodeada de gentes extrañas, lejos de su hijo; pero hasta que cerró los ojos para siempre, no dejó de mirar un retrato de aquel. Era una mujer excelente, muy hospitalaria. Fui a visitarla cuando vivía en X y nunca dejó de obsequiarme con confitura de cerezas. Amaba a su hijo con locura. Los seguidores de la escuela de Petchorín pueden decir que amamos siempre con más pasión a los que son menos dignos de nuestro amor; pero yo creo que todas las madres aman a sus hijos, especialmente a los que están ausentes.

La traductora añade, además, la siguiente nota a pie de página: "Héroe de una novela de Lermontov". Nuevamente hacemos constar la libertad y alejamiento del original de esta traductora. Así, por ejemplo, leemos "una vez separado de su madre" cuando más exactamente sería "desde el extranjero"; "amamos siempre con más pasión a los que son menos dignos de nuestro amor", donde, además de introducir un "con más pasión" no presente en el original, traduce como "son menos dignos" cuando el original dice más precisamente "con poco capaces de amar", como sí traducen otras versiones.

La traducción de R. Cansinos Assens reza del siguiente modo: 
-Del extranjero - siguió diciendo Lechniov-solo escribía a su madre muy rara vez, y antes solo la visitaba una vez cada diez días... La vieja murió, sin tenerlo a su lado, en brazos ajenos; pero hasta el momento de expirar no apartó los ojos de su retrato. Yo iba a verla cuando vivía en $\mathrm{T}^{* * *}$. Era una mujer muy buena y obsequiosa; a mí siempre me ofrecía dulce de ciruela. Amaba a su Mitia con locura. Los señores de la escuela de Pechorinsk le dirán a usted cómo siempre queremos a aquellas personas poco capaces de querer a nadie, pues así creo yo que aman las madres a sus hijos, sobre todo cuando están ausentes.

Sorprendentemente, el traductor no solo no intenta transmitir información del culturema, sino que además parece confundirse con el significado del adjetivo печоринской pechorinskoj (aquí en genitivo singular femenino), creyendo proceder de algún lugar llamado Pechorinsk (terminación característica del nombre de muchas ciudades rusas), cuando en realidad procede del apellido Pechorin, protagonista de la obra Un héroe de nuestro tiempo de Lérmontov, como ya se ha indicado.

Aníbal Leal traduce como esos señores de la escuela Petchorin le dirán que amamos siempre a quienes a su vez tienen muy escasa capacidad para amar, con lo que da la impresión de que Petchorin sea el nombre de alguna escuela; y además no añade ninguna nota aclaratoria.

Finalmente, J. García Gabaldón traduce como los señores de la escuela de Pechorin le dirán a usted que siempre queremos a aquellas personas que son poco capaces de querer, y añade la siguiente nota a pie de página: "personaje principal de la novela Un héroe de nuestro tiempo de Mijail Lérmontov".

\subsection{CUlTURA LingÜÍSTICA}

En las obras de Turguéniev hay numerosos ejemplos de realias, palabras sin equivalente exacto en otras lenguas por designar realidades específicas de una cultura dada. El tema está muy estudiado en el caso de la lengua rusa, así que solo mencionaremos que también en las obras del autor se encuentran vocablos como isbá (típica casa rusa construida con troncos de árboles), samovar (recipiente metálico para hervir agua y preparar té típicamente ruso), la troika rusa (tipo de carruaje tirado por tres caballos), schi y borsch (dos tipos de sopas tradicionales), armiak (tipo de abrigo largo), drochki (pequeño carruaje descubierto de cuatro ruedas), etcétera ${ }^{3}$.

Como culturemas rusos del grupo de cultura linguística podemos destacar el de хохол (hohol) у Хохландия (Hohlandija), formas humorísticas, irónicas y en cierto grado

\footnotetext{
${ }^{3}$ Aunque incluso acerca de esto se podría citar algún caso curioso, como que, a pesar de que el vodka es perfectamente conocido para la mayoría de lectores españoles, Rosa María Turuguet en su traducción de Rudín de 1942 optó por traducirlo como ajenjo: “словно горькой водкой себя попотчевал” (гл. VI) cfr. "como si hubiera tomado un vaso de ajenjo".
} 
despectivas de llamar a los ucranianos y a Ucrania. Los exónimos irónicos son frecuentes en todas las culturas y pueden ser un rasgo que las diferencia de otras, como es este caso, ya que en español no tenemos ninguna forma especial de denominar a los ucranianos. En Rudin encontramos que usa estos términos Pigasov, un personaje socarrón y en cierto modo amargado. Aunque este culturema no tiene una relevancia semiótica elevada para la comprensión de la novela, sí que nos ha parecido un ejemplo curioso de culturema lingüístico. Uno de los pasajes en que aparece es este:

- В Полтавской губернии, мой милейший, - подхватил Пигасов, - в самой Хохландии. (Он обрадовался случаю переменить разговор.) - Вот мы толковали о литературе, - продолжал он, - если б у меня были лишние деньги, я бы сейчас сделался малороссийским поэтом (гл. II).

Para la comprensión de esta intervención hay que saber, además, que Pequeña Rusia o Rusia Menor es el nombre de una región histórica ubicada principalmente en Ucrania (ha ido variando a lo largo de los siglos el territorio comprendido por Pequeña Rusia) y que en muchos casos se usa precisamente como sinónimo de ucraniano.

En la traducción anónima de La España Moderna vemos que no se explica esto ni tampoco el concepto de hohol ni Hohlandija, por lo que a un lector español se le escaparán estas connotaciones irónicas despectivas, así como la plena comprensión de que por Hohlandija se está refiriendo a Pequeña Rusia y por tanto a Ucrania:

-En el gobierno de Poltava, amiguito mío -respondió PIgassoff-, en el mismo centro de la Khokholandia. (Aprovechó este motivo para cambiar el asunto de la conversación.) Puesto que hablamos de literatura, diré que, si tuviese dinero de sobra, me haría poeta pequeño-ruso.

Algo semejante ocurre en la traducción de María Rosa Turuguet, que reza así:

-En el gobierno de Poltava, amiguito -respondió Pigassoff- en el centro de Khokholandia (aprovechó la oportunidad para cambiar el tema de la conversación). Toda vez que hablamos de literatura diré que si tuviera dinero en abundancia me haría poeta de la pequeña Rusia.

R. Cansinos Assens tampoco aclara el culturema en su versión:

-En el gobierno de Poltav, hijito -dijo con énfasis Pigasov-, en la misma Jojlandia - celebraba la ocasión de dar otro giro al diálogo-. Pero estábamos hablando de literatura -siguió diciendo-. Pues bien: si yo tuviera dinero de más, en el acto me haría poeta de la pequeña Rusia.

Aníbal Leal usa también la forma Jojlandia, y aunque no aclara explícitamente en una nota a qué se refiere esa palabra sí se vale de la compensación traduciendo malorossijskij (малороссийский), esto es, 'pequeño ruso', como ucraniano: 
-En la provincia de Poltava, querido -se apresuró a responder Pigassov- en la Jojlandia. Le satisfacía hallar un pretexto para cambiar de conversación.

-Hablábamos de literatura... y bien, si dispusiera de cierta fortuna, me convertiría inmediatamente en poeta ucraniano.

J. García Gabaldón, por último, traduce también como Jojlandia, pero añade la nota: "Alusión a Ucrania".

El personaje incide en este culturema a continuación y contrasta con la opinión de Basistov. El pasaje es el siguiente:

-Да так же, не нужно. Сто́ит только взять лист бумаги и написать наверху: Дума; потом начать так: Гой, ты доля моя, доля! или: Седе казачино Наливайко на кургане!, а там: По-пид горою, по-пид зелено́ю, грае, грае воропае, гоп! гоп! или что-нибудь в этом роде. И дело в шляпе. Печатай и издавай. Малоросс прочтет, подопрет рукою щеку и непременно заплачет, такая чувствительная душа!

-Помилуйте! -воскликнул Басистов- Что вы это такое говорите? Это ни с чем не сообразно. Я жил в Малороссии, люблю ее и язык ее знаю... "грае, грае воропае"-совершенная бессмыслица.

-Может быть, а хохол все-таки заплачет. Вы говорите: язык... Да разве существует малороссийский язык? Я попросил раз одного хохла перевести следующую первую попавшуюся мне фразу: грамматика есть искусство правильно читать и писать. Знаете, как он это перевел: храматыка е выскусьтво правильно чытаты ы пысаты... Что ж, это язык, по-вашему? самостоятельный язык? Да скорей, чем с этим согласиться, я готов позволить лучшего своего друга истолочь в ступе... (гл. II).

El traductor de la versión de La España Moderna reprodujo el pasaje así:

-He aquí cómo. Solo se trata de coger una cuartilla de papel, en lo alto de la cual se escribe "Meditación"; luego se ensartan cierto número de palabras sin sentido ninguno, pero con entonación pequeño-rusa e intención patriótica; se les hace rimar pegue o no pegue, y se publica. El pequeño-ruso lo lee, se apoya sobre los codos y de fijo que llora. ¡Es un alma tan impresionable!

-¡Por el cielo! - exclamó Bassistoff-¿QQué dice V. ahí? Eso no tiene sentido común. He vivido en la Rusia Menor, me gusta aquella lengua, la conozco... Eso que nos cuenta V. es increíble.

-Posible será, pero no por eso llora menos el Khokhol. ¿Lengua, dice V.?... ¿Acaso existe una lengua pequeño-rusa? Una vez pedí a un khokhol que me tradujera la primera frase que se me ocurriese, por ejemplo, esta: “Gramática es el arte de hablar y escribir correctamente” ¿Sabe V. cómo la tradujo, y de qué lengua se valió? De la lengua rusa, solo que convirtiendo las $i$ en $y$, y pronunciando de un modo gutural y duro que destrozaba el tímpano. ¿Cuál es, pues, esa lengua, según V. la llama? ¿Es una lengua independiente? Antes que admitir eso, me resignaría a majar a mi mejor amigo en un mortero. 
La traducción de Rosa María Turuguet suena así:

-He aquí por qué. Para ser poeta de esa índole no hace falta más que un trozo de papel, en lo alto del cual se escribe: "Meditación". A continuación se hace acopio de un cierto número de palabras, aunque carezcan de sentido, pero que tengan una entonación pequeño-rusa e intención patriótica: se las hace rimar bien o mal, y se publican. El pequeño-ruso lo lee, apoya la cabeza en sus manos e, inevitablemente, llora. iEs tan impresionable!

-iPor Dios! clamó Bassistoff-. ¿Qué dice usted? Esto no tiene sentido. He vivido en la Rusia Menor, me gusta su idioma, lo conozco... Lo que está diciendo es increíble...

-Es posible. Pero no por esto el Khokhol lloraría menos. ¿Idioma, ha dicho? ¿Existe por casualidad un idioma pequeño-ruso? Cierta vez pedí a un Khokhol que me tradujera una frase cualquiera; esta, por ejemplo: la gramática es el arte de hablar y escribir correctamente. ¿Sabe cómo la tradujo y de qué idioma se valió? Pues del ruso, substituyendo las $i$ por $y$, y pronunciando de una manera gutural y ruda, que destrozaba los oídos. ¿Qué idioma es, pues, este? ¿Un idioma independiente? Antes de admitir esto, preferiría machacar a mi mejor amigo en un mortero...

En su traducción vemos, además, que se ha valido de las técnicas de la transposición para intentar transmitir al español las imitaciones que hace Pigasov de cómo suena el ucraniano (zpae, zpae вoponae, zon! zon! igrae, grae voropae, gop! igop!) y de la traducción libre y la descripción (traduce Гой, ты доля моя, доля! или: Седе казачино Наливайко на кургане!, а там: По-пид горою, по-пид зелено́ю comо se hace acopio de un cierto número de palabras, aunque carezcan de sentido, pero que tengan una entonación pequeño-rusa e intención patriótica: se las hace rimar bien o mal).

R. Cansinos Assens omite en su versión las onomatopeyas del original y acorta la primera intervención de Pigasov, aunque intenta reproducir la frase que este personaje le pidió traducir al ucraniano y que en la versión de Turuguet veíamos que se había adaptado más libremente:

-Y no lo es. Basta con coger una hoja de papel y escribir en ella: ¡arriba Idea! ¡Oh sino mío, sino mío, o algo por el estilo [sic; sin cierre de comillas en el original]. Y ya está. Lo imprime usted y se lo da a leer a un pequeño ruso y en seguida se lleva el hombre la mano a la mejilla e infaliblemente rompe a llorar... ¡Oh, qué alma tan sensible!

-Por favor -exclamó Basitov-. ¿A qué dice usted esas cosas? Son absolutamente incongruentes. Yo he vivido en la pequeña Rusia, le tengo cariño y conozco su lengua... y todo eso que ha dicho usted es un puro despropósito.

-Puede que así sea... Pero hace llorar al pequeño ruso... Dice usted lengua... Pero ¿es que hay una lengua pequeño-rusa? Yo le pedí una vez a un pequeño ruso que me tradujese la siguiente frase, la primera que se me ocurrió: "La Gramática es el arte de leer y escribir correctamente”. Y ¿sabe usted cómo me la tradujo? Pues: "La 
Jramatica es el arte de leder y escrebir correctamente". Y esto, según usted, ¿es una lengua? ¿Una lengua independiente? A quien eso sostuviera, aunque fuese mi mejor amigo, yo lo haría majar en un mortero...

De este pasaje llama la atención especialmente la traducción de Aníbal Leal por ser la que más se aleja en cuanto a técnica respecto de las otras versiones y por ser la que más intenta representar las palabras rusas del original tal cual, acompañadas de su traducción. En su versión el fragmento queda así:

-iNaturalmente! Es suficiente tomar una hoja de papel y escribir arriba: Pensamiento... después, comenzar así: " $; O h !$ Destino, mi destino"... "El cosaco Nalivaiko tendido sobre el túmulo"... y después: "Entre las montañas, atravesando los grandes valles, hup, hup, graié, graié, voropaié", o algo por el estilo... y iya está! Solo falta imprimir y editar... El pequeño ruso lo leerá, inclinará la cabeza sobre la mano y no dejará de llorar... ¡Son almas tan sentimentales!

-iPerdón, perdón! - exclamó Bassistov-. ¿Qué está diciendo? Eso no significa nada.

Viví en Ucrania y conozco el idioma. "Graié, graié, voropaié" es una perfecta insensatez.

-Es posible... pero de todos modos el jojol romperá a llorar. Usted habla del idioma... pero el pequeño ruso, jrealmente existe? Cierto día pedí a un ucraniano que tradujera la primera frase que se me ocurrió: "La gramática es el arte de leer y escribir bien". Vean cómo tradujo: "chra en lugar de grammática, viss en lugar de isscoustvo (arte); tchitati en lugar de tchitat (leer) y pissati (escribir)... ¿Llama lengua a esto? Antes que afirmarlo, preferiría permitir que se moliese en un mortero a mi mejor amigo...

J. García Gabaldón opta por transcribir la imitación de cómo suena el ucraniano para un ruso (grae, grae; voropae, hop, hop) y para la traducción de la frase que hizo el ucraniano se vale de la jramática es el aarte de leder y escribir vien.

Dentro de los culturemas linguísticos uno de los grupos más estudiados es el de los fraseologismos. Veamos este breve fragmento de la novela:

- Да уж я думаю, Дарья Михайловна, -возразил с досадой Пигасов,-что вам, во всяком случае, легче было бы жить без истины, чем без вашего повара Степана, который такой мастер варить бульоны! И на что вам истина, скажите на милость? Ведь чепчика из нее сшить нельзя!

- Шугка не возражение, -заметила Дарья Михайловна, -особенно, когда сбивается на клевету...

- Не знаю, как истина, а правда, видно, глаза колет, -пробормотал Пигасов и с сердцем отошел в сторону (гл. III).

Encontramos aquí un doble culturema de tipo linguístico. Por un lado, el del fraseologismo ruso правда глаза колет, en principio con gran afinidad en la cultura española pues equivale a la verdad duele (u ofende). Pero por otro lado el de la distinción 
en ruso entre los conceptos de правда pravda е истина istina. Son conceptos complejos de los que se han escrito libros enteros. En la segunda edición (1880-1882) del Diccionario de la lengua rusa viva de V. I. Dal' (1801-1872) se definía istina como lo contrario a la mentira; todo lo que es cierto, verdadero, exacto, justo, que es; [...] Istina procede de la tierra (es una propiedad del raciocinio del hombre), mientras que pravda [del indoeuropeo *prew-, relacionado con el lat. probus y el esp. ímprobo] procede de los cielos (un don de bendiciones). La istina está relacionada con el juicio y la razón; mientras que la bondad y el bien [pravda] con el amor, la moral y la voluntad ${ }^{4}$.

¿Cómo han resuelto los traductores esta cuestión? El traductor de La España Moderna del siguiente modo:

-En todo caso - respondió con acritud Pigassoff- más fácil sería para V. vivir sin la verdad que sin su cocinero Stepan, que es maestro consumado en su arte. Y dígame, por favor, ¿qué falta le hace á V. la verdad? ¿Puede servir para arreglar trapos? -Burlarse así no es responder -interrumpió Daría.

-Yo no sé si la verdad salta a la vista, pero parece que eso lo hace la sinceridad -murmuró Pigassof, volviéndose con ira á su rincón.

El traductor ha tratado de reflejar de algún modo esa distinción que hace el ruso entre pravda e istina con bastante acierto, ya que cuando hablamos de que la verdad duele nos estamos refiriendo en cierto modo a la sinceridad, a que se nos digan abiertamente las verdades que no nos gusta.

Menos exacto es, no obstante, traducir la expresión глаза колет como salta a la vista, ya que significan cosas distintas en cada idioma; aunque se percibe el intento del traductor por mantener la imagen de los ojos del original con alguna expresión similar en la lengua meta.

María Rosa Turuguet traduciendo el pasaje del siguiente modo:

-En todo caso -respondió con acento agrio Pigassoff- le sería más fácil a usted vivir sin la verdad que con Stepan, su cocinero. Y dígame, por favor, ¿qué necesidad tiene de la verdad? ¿Puede servir para arreglar lo que no vale la pena? -Bromear, no es responder -atajó Daria Micaelovna.

-No sé si la verdad ciega, pero parece que eso lo hace la sinceridad -murmuró Pigassof, regresando colérico a su rincón. [la cursiva es nuestra]

\footnotetext{
${ }^{4}$ Según Yu. S. Stepanov, el concepto designado en las lenguas europeas por palabras como truth (ingl.), vérité (fr.) o Wahrheit (al.) se corresponderían más bien con el concepto ruso de истина, con lo que la noción rusa de правда quedaría desconceptualizada en dichas lenguas. En el ruso actual istina se relaciona, más bien, con lo eterno e inamovible, la verdad en su sentido absoluto y aun teológico, mientras que pravda es algo más terrenal, mudable, social [vid. Степанов 2004, pp. 455 y ss.]. La frase de San Juan “La verdad os hará libres" en ruso es “Истина сделает вас свободными".

188 | AlPHA № 52 (JuLIO 2021) PÁGS. 163-193. ISSN 07 16-4254
} 
Y añade una nota a pie de página con la siguiente aclaración: Alusión a un proverbio ruso: "La verdad ciega".

En la versión de Aníbal Leal la réplica de Pigasov suena así: “¿Cuál puede ser el efecto de lo verdadero... cuando la sinceridad irrita y lastima los ojos?". Transmitiendo el sentido e intentando conservar la imagen fraseológica con ojos del original ruso, aun cuando no sea idiomático en español.

R. Cansinos Assens, ni hace la distinción entre estos dos conceptos en su versión, ni parece haber entendido la expresión правда глаза колет, уa que traduce la última intervención de Pigasov como: "No sé lo que sea la verdad, pero salta a la vista".

\section{CONCLUSIONES}

El estudio de las especificidades culturales, y de sus unidades semióticas, los culturemas, aplicado a la traductología es de gran relevancia hoy en la bibliografía científica. Tanto que se llega a hablar de traducción de cultura de partida a cultura de llegada. No obstante, hay una elevada diversificación de términos y conceptos (piénsese en los términos más o menos equivalentes entre sí o sinónimos usados por distintos autores como son los elementos culturales, los ámbitos culturales de Nida, las palabras culturales de Newmark, los indicadores culturales de Nord o conceptos como los de realia, culturema o linguoculturema).

En el presente artículo hemos recogido y desarrollado los principales criterios para definir e identificar un culturema en el sentido exacto en el que lo usamos nosotros, más exactamente en su concepción de unidad semiótica cuyo referente es un elemento perteneciente a una cultura dada desconocido o sin equivalente exacto en otras culturas y que, por tanto, es percibida como una especificidad cultural. Aplicado a la teoría de la traducción nos referiríamos específicamente a unidades del plano de la expresión referidas a realidades o contextos histórico-sociales presentes en el texto original propios de la cultura de partida, pero de difícil transmisión al receptor de otra cultura. Los culturemas pueden materializarse verbalmente en el texto de partida o pueden estar implícitos en el conocimiento de los receptores nativos del texto. Finalmente, frente a otros fenómenos similares, el culturema se define por los cuatro criterios señalados por L. Luque Nadal (1. Vitalidad, figuratividad y motivación, 2. Productividad fraseológica, 3. Frecuencia de aparición, 4. Complejidad estructural y simbólica) más los de intersemiosis y contextualidad, de los que ya hemos hablado.

Asimismo, más allá de las clasificaciones tradicionales de los diferentes autores por su contenido referencial (por ejemplo, la que hace Nida distinguiendo entre 1. Ecología, 2. Cultura material, 3. Cultura social, 4. cultura religiosa y 5. Cultura lingüística) y que hemos revisado en el presente artículo, en un estudio traductológico deberemos atender también a la distinción de culturemas presentes en un texto traducido a otra lengua por su relevancia semiótica (alta, media o baja). El culturema deja de ser, 
por tanto, un concepto abstracto teórico para pasar a ser algo contextualizado en cada texto concreto. La relevancia semiótica de un culturema dado puede ser alta en una obra pero baja en otra distinta. El culturema debe entenderse, entonces, como una noción flexible, abierta, viva y contextualizada.

El análisis de culturemas presentes en una traducción dada debe seguir, por tanto, un procedimiento culturo-traductológico, esto es, una combinación entre análisis traductológico (estrategias de traducción seguidas por el traductor, problemas de traducción presentes en el texto original, análisis de técnicas de traducción empleadas, estudio de la función y objetivo de la traducción, etc.) y exégesis cultural-literaria.

A la hora de enfrentarnos a un análisis traductológico de culturemas en una traducción dada deberemos tener en cuenta los seis pasos del procedimiento culturotraductológico indicados en el artículo.

Nosotros hemos aplicado el procedimiento culturo-traductológico de análisis de culturemas en la obra Rudin de Iván Turguéniev y hemos llegado a algunas conclusiones muy interesantes, sin perjuicio de otras conclusiones que puedan derivarse de este estudio por nuestra parte o por parte de cualquier lector.

Así por ejemplo, los culturemas del tipo que hemos denominado ecología llenan el texto original de sutiles y agudas alusiones o connotaciones, pero no llegan a tener por regla general una relevancia semiótica elevada para la comprensión de la novela. Con frecuencia los traductores transmiten el sentido denotativo que hay tras estos culturemas, aunque a veces a costa de sacrificar el colorido y la vitalidad que transmite el culturema en el original.

Los culturemas de la llamada cultura material suelen ser también de relevancia semiótica baja. En general se observa que, como en todas las culturas suelen haber objetos parecidos o que vagamente se asemejan en forma o función a los de los culturemas de este grupo, los traductores se valen de esos equivalentes cercanos, cayendo a veces en una deformación del cuadro retratado en el original o, por supuesto, del color local.

Los culturemas del tercer grupo, los de la cultura social, suelen tener una mayor relevancia que los dos anteriores, pues pueden presentar personajes, cargos, instituciones o costumbres relevantes para la comprensión del texto. Un problema difícil de solucionar desde el punto de vista traductológico que presentan estos culturemas es que, debido a la influencia occidentalizante generalizada, sobre todo a partir de la cultura francesa y parcialmente de Inglesa o Alemana, el referente del culturema puede existir tanto en la cultura de partida como en la de llegada (pensemos en la institutriz), pero que las connotaciones implícitas difieran de una cultura a otra y no se perciba por parte del lector.

Los culturemas de la cultura espiritual son muy numerosos, variados y complejos. Su función y relevancia semiótica en el texto pueden ser muy distintas. El trabajo del traductor debe ser, si es posible, más meticuloso a la hora de identificar y trasladar los culturemas de este grupo, lo que no siempre es fácil a menos que se recurra a técnicas 
traductológicas de amplificación, compensación, descripción, modulación o incluso adaptación, además del uso de notas aclaratorias.

Los culturemas de la cultura lingüística suponen un grupo de difícil traslado en ocasiones a la lengua meta precisamente por su naturaleza linguiística, y en este aspecto representan el auténtico nudo gordiano del traductor a la hora de enfrentarse a un texto original. Si la dificultad de otros culturemas es una cuestión de fondo, la de los de este grupo lo es, además, de forma.

La recopilación de todos los datos obtenidos con el estudio de los culturemas presentes en una obra dada (en este caso Rudin) nos permite tener un material muy amplio a la hora de la exégesis literaria de la obra y del estudio cultural, social e histórico de la cultura que hay detrás del texto original.

\section{OBRAS CITADAS}

Catford, John Cunnison (1965). A linguistic Theory of Translation. An Essay in Applied Linguistics. London: Oxford University Press, [Trad. a español de F. Rivera: Una teoría lingüística de la traducción. Ensayo de lingüística aplicada. Caracas: Universidad Central de Venezuela, 1970).

Eyckmans, June (2017). Cultural Competence in Translation Studies and Its Assessment. In J. Deconinck et al. (eds.). Towards Transcultural Awareness in Translation Pedagogy (pp. 209-229). Berlin/Zürich: LIT Verlag,

Hurtado Albir, Amparo (2001 [2a ed. 2004]). Traducción y Traductología. Introducción a la Traductología. Madrid: Cátedra.

$\mathrm{Ku}$, Menghsuan (2006). La traducción de los elementos lingüísticos culturales (chinoespañol). Estudio de Sueño en las estancias rojas [tesis doctoral]. Barcelona: Universitat Autònoma de Barcelona. $<$ https://www.tdx.cat/bitstream/handle/10803/5265/mk1de2.pdf?seq $>$.

Luque Durán, Juan de Dios (2001). Aspectos universales y particulares del léxico de las lenguas del mundo. Serie Granada Lingvistica. Granada: Granada Lingvistica.

Luque Nadal, Lucía (2009). Los culturemas: ¿unidades linguísticas, ideológicas o culturales?. Language Design, 11, 93-120 <http://elies.rediris.es/Language_Design/LD11/LD11-05-Lucia.pdf>.

Molina Martínez, Lucía (2006). El otoño del pingüino: análisis descriptivo de la traducción de los culturemas. Castellón de la Plana: Publicaciones de la Universitat Jaume I.

— (2001). Análisis descriptivo de la traducción de los culturemas árabe-español [tesis doctoral]. Barcelona: Universitat Autònoma de Barcelona <https://www.tdx.cat/handle/10803/5263>. 
Nida, Eugene A. (1975). Exploring semantic structures. München: Wilhelm Fink Verlag. (1959). Principles of Translation as exemplified by Bible Translating. In R. A. Brower (ed.). On translation (pp. 11-31). Cambridge: Harvard University Press.

_ (1945). Linguistics and Ethnology in Translation-Problems. Word, 1 (2), 194-208.

Pamies Bertrán, Antonio (2013). De lingüística, traducción y léxico-fraseología. Homenaje a Juan de Dios Luque Durán. Granada: Comares.

Pardo Bazán, Emilia (1961). La Revolución y la novela en Rusia. Madrid: Publicaciones españolas.

Poyatos, Fernando (1976). Man Beyond Words: Theory and Methodology of Nonverbal Communication [New York State English Council monographs, $n^{\circ}$ 15]. New York: New York State English Council.

Vercher García, Enrique J. (2008). La transmisión al ruso de especificidades culturales españolas en las traducciones de "Don Quijote" de K. P. Masal'skij y N. M. Ljubimov [tesis doctoral]. Bologna: Università di Bologna <http://amsdottorato.unibo.it/1028/> [Revisada y publicada como Vercher García, Enrique J. (2011). Don Quijote entre las nieves. Alcalá de Henares: Centro de Estudios Cervantinos].

Vinay, Jean-Paul; Darbelnet, Jean (1958). Stylistique comparée du français et de l'anglais. Méthode de traduction. Paris: Didier.

Wierzbicka, Ana (1992). Semantics, Culture and Cognition. Oxford: Oxford University Press.

Анненков, Павел Васильевич (1875-1883). Письма к И.С. Тургеневу / Изд. Н.Н. Мостовская, Н.Г. Жекулин. Санкт-Петербург: Наука.

Беляев, Александр Сергеевич (2000). Язык и культура в понимании Б. Малиновского: $K$ постановке проблемь // Единицьь языка и их функиионирование: Межвуз. сборник научных трудов. Bып.6. Саратов: СГАП.

Быкова, Г.В. (1998). Лакунарность как лингвистическое явление. Научный альманах, $\quad$ 12-3(14), $\quad 393-395 . \quad$ DOI: $\quad 10.17117 /$ na.2015.12.03.393 <http://ucom.ru/doc/na.2015.12.03.393.pdf>.

Вежбицкая Анна (1996). Язык. Культура. Познание. Москва: Русские словари.

Влахов, Сергей; Флорин, Сидер (1980 [2-е изд. 1986]). Непереводимое в переводе. Москва: Высшая школа.

Гудавичюс, Эдвардас (1993). Глубинный уровень отражения культуры в лексической семантике. In А. Гудавичюс. Исследования по семантике (c. 1623). Уфа: БГУ. 
El análisis culturo-traductológico en traducción. Sobre el material de culturemas en Rudin

Добровольский, Дмитрий О. (1997). Национально-культурная специфика во фразеологии. Вопросы языкознания, 6, 37-48.

Кабашникова, Ольга Алексеевна (2017). Национально-культурная специфика семантики языковых единиц. Евразийский Научный Журнал, 11 [online] $<$ http://journalpro.ru/articles/natsionalno-kulturnaya-spetsifika-semantikiyazykovykh-edinits/>.

Красных В. В. (2002). Этнопсихолингвистика и лингвокультурология: Курс лекций. Москва: Гнозис.

Маслова, Валентина Авраамовна (2004). Лингвокульурология (2-е изд.). Москва: Academia.

VV.AA. (2003-2019). Национальный Корпус Русского Языка <www.ruscorpora.ru>.

Попова, 3. Д., Стернин И. А. (2002). Язык и национальная картина мира. Воронеж: Истоки.

Степанов, Юрий (1997 [3-е изд. 2004]). Константьл: словарь русской культуры. Москва: Академический проект.

Супрун, Адам Е. (1958). Экзотическая лексика. Научные доклады выстией школьл. Филологические науки, 2, 51-54.

Фирсова, Наталия Михайловна (1991). Национально-культурная специфика вербальной коммуникации в испанском языке. In Национально-культурная специфика речевого поведения (с. 9-11). Москва: Наука.

Швейцер, А. Д. (1973). Перевод и лингвистика. Москва: Воениздат.

\section{EDICIONES Y TRADUCCIONES DE RUDÍN (1857)}

Тургенев, И. С. (2009). Рудин. Санкт-Петербург: Азбука-классика.

— (1980). Рудин. In И. С. Тургенев. Полное собрание сочинений и писем 8 тридцати томах. T. 5. Москва: Наука https://ilibrary.ru/text/1198/index.html.

Turguenef [sic] (1893). Demetrio Rudín. Traducción anónima. La España Moderna. Revista Ibero-Americana, LVII, 5-106 [publicado también en forma de libro en Madrid: La España Moderna].

Turguéniev, I. S. (1997). Rudin. Traducción de Jesús García Gabaldón. Barcelona: Alba.

— (1981). Dimitri Rudin. Traducción de Aníbal Leal. Buenos Aires: Javier Vergara Editor.

— (1954). Demetrio Rudín. Traducción anónima. Revista literaria. Novelas y cuentos, 1.189, 1 (513)-60 (572).

— (1951). Rudin. In Turguenev, I. S. Obras escogidas. Traducción de Rafael Cansinos Assens. Madrid: Aguilar.

— (1942). Demetrio Rudín. Traducción de María Rosa Turuguet. Barcelona: Nausica. 